\title{
PEMBERDAYAAN WANITA TANI DENGAN PELATIHAN PEMBUATAN POT ORGANIK DARI JERAMI PADI DAN LIMBAH DAUN BAWANG MERAH
}

\author{
Jauhari Syamsiyah, Aktavia Herawati*, Mujiyo \\ ${ }^{1}$ Program Studi Ilmu Tanah, Fakultas Pertanian, Universitas Sebelas Maret \\ Jl. Ir. Sutami 36 A Kentingan Surakarta \\ Korespondensi: aktavia_h@staff.uns.ac.id
}

\begin{abstract}
ABSTRAK
Pot organik berbahan dasar campuran jerami padi dan limbah daun bawang merah merupakan inovasi baru untuk memanfaatkan bahan tersebut yang melimpah di lingkungan. Desa Srigading merupakan sentra pertanaman padi dan bawang merah. Setiap musim panen tiba, limbah hasil panen tersebut dibuang begitu saja. Padahal biomassa ini bisa dimanfaatkan untuk pot organik. Pot organik dari limbah jerami padi dan daun bawang merah dapat lebih aman dan tidak membuat pencemaran tanah dan lingkungan. Limbah jerami dipilih karena mengandung selulosa dan lignin yang tinggi. Selulosa dapat membentuk ikatan yang kuat antar molekulnya. Kandungan selulosa yang tinggi tersebut menjadikan jerami berpotensi sebagai bahan pembuatan pot biodegradable. Selain itu jerami mengandung bahan organik yang berperan penting dalam merekatkan butiran tanah membentuk agregat tanah yang lebih mantap. Daun bawang merah diyakini mengandung zat kitin yang tinggi, sehingga berpotensi sebagai penahan air dalam pot. Selain itu jerami padi dan daun bawang merah merupakan bahan organik yang mengandung berbagai unsur hara yang lengkap. Sehingga selain sebagai bahan baku pot, jerami padi dan daun bawang merah juga berfungsi sebagai cadangan unsur hara untuk tanaman dalam pot. Kombinasi jerami padi dan daun bawang merah diharapkan mampu menjadi alternatif pot organik yang ramah lingkungan, murah serta mudah diadopsi oleh masyarakat. Berdasarkan hal tersebut, limbah jerami padi dan daun bawang merah mempunyai potensi yang cukup strategis untuk dimanfaatkan menjadi pot organic/biodegradable. Pengabdian ini bertujuan untuk memanfaatkan limbah jerami padi dan daun bawang merah menjadi pot organik yang murah dan mudah diterapkan dan untuk peningkatan perekonomian masyarakat setempat. Penyuluhan tentang manfaat jerami, daun bawang merah dan pupuk kendang sebagai bahan pot telah dilaksanakan pada tanggal 21 Juni 2019. Hasil menunjukkan bahwa peserta antusias mengikuti kegiatan penyuluhan dan praktek pembuatan pot organic berbahan dasar jerami padi, daun bawang merah dan lempung.
\end{abstract}

Kata kunci: pot organic, jerami padi, daun bawang merah, lempung

\section{PENDAHULUAN}

Desa Srigading merupakan desa penghasil bawang merah terbesar di Kabupaten Bantul. Berbagai varietas bawang merah lokal maupun impor dibudidayakan oleh petani setempat. Varietas lokal yang menjadi primadona adalah Tiron. Menurut Badan Pusat Statistik Provinsi DIY (2016), produksi terbesar bawang merah tahun 2015 terdapat di Kabupaten Bantul yaitu 4.479 ton dengan luas $585 \mathrm{Ha}$. Sedangkan pada tahun
2016, luas lahan meningkat menjadi $768 \mathrm{Ha}$ dengan produksi mencapai 7.904 ton (BPS, 2017). Dengan menerapkan pola tanam PadiBawang Merah Musim Tanam I (bulan AprilJuni) - Bawang Merah Musim Tanam II (bulan Juli-September)- Padi menyebabkan limbah jerami dan daun bawang merah sangat melimpah di wilayah ini. Sampai saat ini belum ada yang memanfaatkan limbah tersebut. Jerami hanya sesekali digunakan untuk makanan ternak, sedangkan jumlahnya 
sangat melimpah. Daun bawang merah hanya dibuang begitu saja, bahkan kadang ada yang dibakar.

Bawang merah merupakan tanaman umbi-umbian. Bagian bawang merah yang bernilai ekonomis tinggi adalah umbinya. Pemanenan bawang merah dengan cara memotong antara trubus dan umbi. Umbi ini selanjutnya akan dibersihkan lalu dijual. Pemerintah Daerah Kabupaten Bantul telah menunjukkan kepeduliannya terhadap petani bawang merah dengan cara membangun gudang penyimpangan umbi bawang merah. Gudang ini terletak di dusun Sogesanden Desa Srigading. Tujuan pembangunan gudang penyimpanan bawang merah yaitu untuk menyimpan bawang merah ketika panen raya tiba. Pada saat panen raya produksi bawang merah sangat melimpah sehingga harga cenderung murah. Oleh karena itu untuk menjaga nilai jual maka bawang merah hasil panenan sebagian disimpan untuk dijual kembali pada saat musim tanam. Sehingga petani akan mendapatkan keuntungan.

Sedangkan trubus/daun bawang merah sejauh ini belum dimanfaatkan oleh petani, padahal jumlahnya sangat melimpah. Biasanya para petani hanya menumpuk atau membakar limbah daun bawang merah. Daun bawang merah diyakini mengandung zat kitin. Zat kitin merupakan lapisan anti air, sehingga daun bawang sulit meloloskan air. Melihat peluang adanya peningkatan nilai ekonomis dari daun bawang merah di Desa Srigading, maka dilakukan kegiatan pengabdian tentang pemanfaatan limbah daun bawang merah sebagai campuran bahan pot organik

Pot organik merupakan pot atau bahan semai yang pembuatannya menggunakan bahan organik yang ramah lingkungan. Beberapa jenis bahan organik telah dicoba dikembangkan untuk pot organik antara lain adalah campuran tanah liat, kertas koran dan kotoran sapi (Khan et al., 2000), serat bulu, seresah dan kompos (Amstrong, 2003). Bahan dasar pot organik seperti seresah, kompos, kotoran sapi, kertas, serat bulu mempunyai keunggulan mudah terdekomposisi dan dapat menyumbang unsur hara cukup banyak. Kelemahan kertas bekas adalah kemungkinan mengandung logam berat.

Prospek pemakaian pot organik yang bersahabat dengan lingkungan akan semakin diperlukan dan menjadi peluang komoditi yang dapat dipasarkan. Oleh karenanya standar bahan baku tersebut harus berwawasan lingkungan dengan memenuhi syarat 4R yaitu Reduce of Energy, Reuse, Replace dan Recycle. Sehingga pemilihan bahan baku pot berupa limbah daun bawang merah dan limbah jerami merupakan pilihan yang tepat. Selain keberadaannya melimpah, kedua bahan ini juga mempunyai fungsi yang spesifik dalam mendukung kualitas pot organik. Limbah jerami dipilih karena mengandung selulosa dan lignin yang tinggi. Selulosa dapat membentuk ikatan yang kuat antar molekulnya. Selain itu jerami mengandung bahan organik yang berperan penting dalam merekatkan butiran tanah membentuk agregat tanah yang lebih mantap. Daun bawang merah diyakini mengandung zat kitin yang tinggi, sehingga berpotensi sebagai penahan air dalam pot. Selain jerami padi dan daun bawang merah, kotoran kandang juga digunakan sebagai bahan perekat. Kotoran kandang ini mengandung bahan organik yang memiliki berbagai unsur hara yang lengkap. Sehingga selain sebagai bahan baku pot, kotoran kandang juga berfungsi sebagai cadangan unsur hara untuk tanaman dalam pot. Pot organik yang ramah lingkungan dianggap praktis karena dapat langsung ditanam ke dalam tanah tanpa harus membuka wadah. Selain itu pot organic diharapkan dapat terdekomposisi secara cepat serta tidak menyebabkan kerusakan lingkungan. 
Kegiatan pengabdian ini dilaksanakan di Desa Srigading, Kecamatan Sanden, Kabupaten Bantul. Sebagian besar penduduknya bermata pencaharian sebagai petani bawang merah. Hal ini dilakukan karena selain tanahnya subur dan ketersediaan sumber air melimpah. Mitra yang bekerja sama dengan Program PKM ini adalah wanita tani yang tergabung dalam Kelompok Pengajian Nailul Hidayah yang berada di Dusun Sogesanden.

Tujuan umum pengabdian ini adalah sebagai pelaksanaan salah satu Tridharma Perguruan Tinggi yaitu pengabdian kepada masyarakat dalam bentuk penerapan ilmu pengetahuan dan teknologi kepada masyarakat, untuk pemberdayaan wanita tani serta meningkatkan daya saing perekonomian masyarakat khususnya di sentra bawang merah Desa Srigading, Kecamatan Sanden Kabupaten Bantul. Tujuan khusus kegiatan ini adalah membantu penguatan kelembagaan kelompok wanita tani, mengimplementasikan teknologi tepat guna pembuatan pot organik berbahan limbah jerami dan daun bawang merah, menawarkan alternatif pemanfaatan limbah pertanian berupa jerami dan daun bawang merah menjadi produk yang bernilai ekonomis, dan meningkatkan ketrampilan masyarakat dalam pengolahan limbah pertanian menjadi produk bernilai ekonomis menggunakan teknologi sederhana.

Beberapa penelitian dan pengabdian secara komprehensif telah dilakukan untuk menerapkan IPTEKS di masyarakat. Akan tetapi sampai saat ini belum ada penelitian dan pengabdian yang fokus terhadap limbah pasca panen yang berupa jerami dan daun bawang merah. Oleh karena hal tersebut di atas, melalui kegiatan ini, bidang kajian kimia dan kesuburan tanah sangat diperlukan peran sertanya agar dapat membantu dalam memberikan rekomendasi teknologi pasca panen untuk pengelolaan limbah jerami dan daun bawang merah. Hasil akhir dari kegiatan ini adalah terciptanya formulasi terbaik pot organik berbahan dasar limbah jerami dan daun bawang merah sebagai wadah/media tanam. untuk mewujudkan perekonomian masyarakat yang lebih tangguh.

\section{METODE}

Teknologi pembuatan pot organik berbahan limbah jerami padi dan daun bawang merah telah diimplementasikan di lokasi mitra yaitu di Dusun Sogesanden Desa Srigading Kecamatan Sanden, Kabupaten Bantul. Mitra yang tergabung dalam kegiatan ini adalah Majelis Taklim Nailul Hidayah. Metode yang dilakukan adalah dengan memberdayakan masyarakat (participatory rural appraisal) untuk membuat pot organik. Metode pendekatan ini menekankan pada inovasi dan teknologi dari pelaksana PKM kepada mitra (petani) dengan harapan aspek keberlanjutan pasca-kegiatan dapat berjalan terus. Mitra dituntut untuk berpartisipasi aktif melalui penyediaan bahan yang akan digunakan sebagai bahan pembuatan pot organik dan penyediaan sumberdaya manusia sebagi subyek untuk dilatih.

Kegiatan pemberdayaan dilakukan dengan pendekatan dan pelatihan serta pendampingan masyarakat/mitra. Pelaksanaan kegiatan pemberdayaan dilakukan melalui langkah-langkah sebagai berikut:

1. Analisis situasi lokasi untuk mengetahui permasalahan, potensi dan solusi untuk mengatasi permasalahan mitra

2. Sosialisasi program dengan mitra untuk menyamakan persepsi mengenai rencana kegiatan pemberdayaan

3. Pelatihan pembuatan pot organik menggunakan bahan jerami padi dan daun bawang merah

4. Pengujian hasil praktek pembuatan pot

5. Evaluasi hasil pengujian dan penentuan prioritas pengembangan pot organik. Hasil pelaksanaan program dievaluasi melalui pengamatan secara langsung, penyebaran kuesioner tentang manfaat kegiatan, dan kemungkinan pengembangan secara komersial untuk meningkatkan perekonomian masyarakat. 


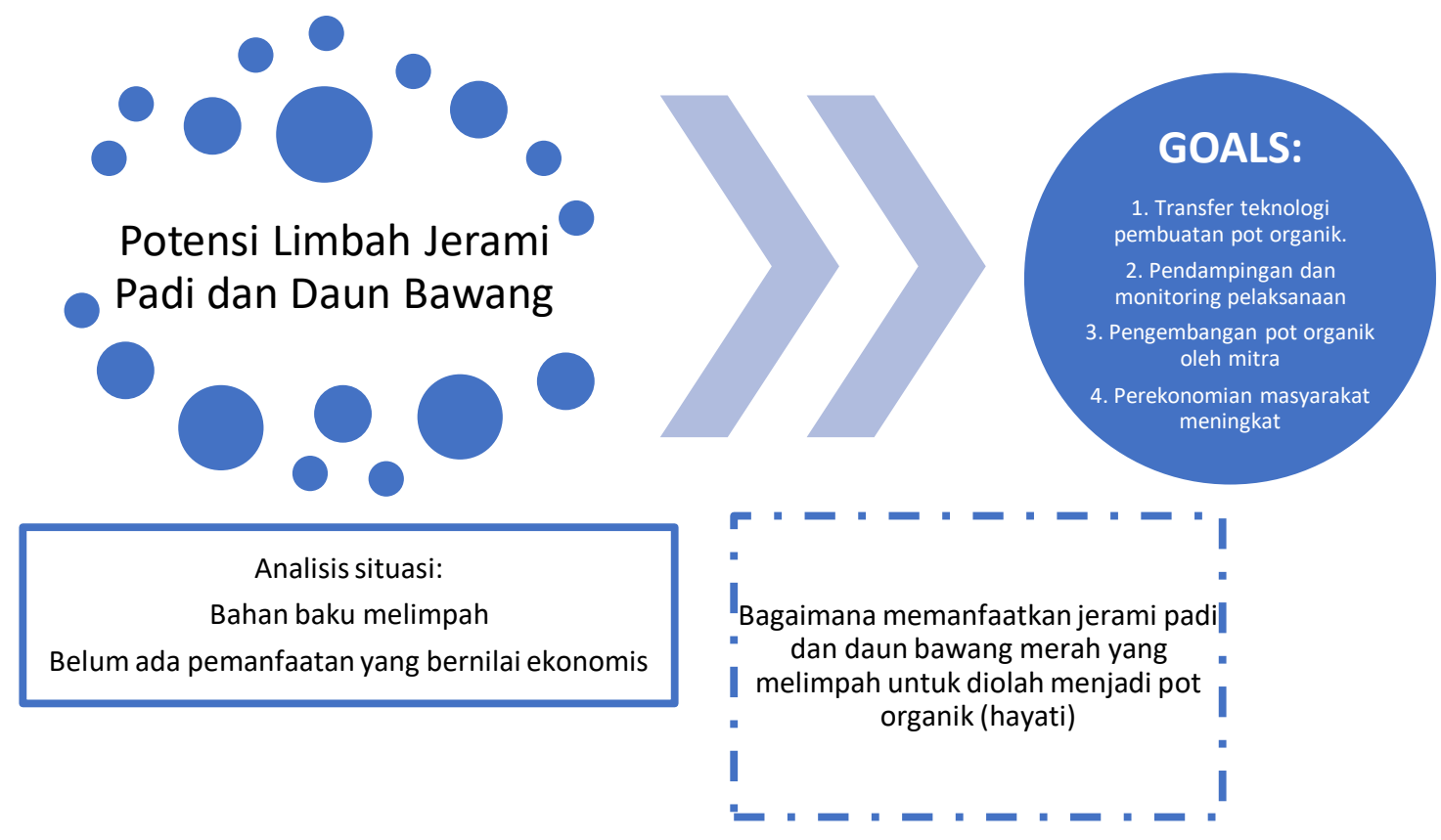

Gambar 1. Alur kegiatan yang dilakukan

\section{HASIL DAN PEMBAHASAN}

\section{Kegiatan Focus Group Discussion (FGD)}

Kegiatan FGD dilakukan oleh Tim Pengabdi sebanyak empat kali. (1) FGD pertama bertujuan untuk menggali informasi tentang permasalahan dan kebutuhan yang dihadapi mitra untuk diperoleh solusi terbaik. Hasil FGD menunjukkan bahwa masyarakat ingin memanfaatkan limbah jerami padi dan daun bawang merah menjadi barang yang bernilai ekonomis tinggi (2) FGD kedua mendiskusikan tentang rencana pengajuan proposal melalui skema Program Kemitraan Masyarakat dana PNBP Universitas Sebelas Maret tahun 2019 dan tahap tahap pelaksanaan kegiatan. (3) FGD ketiga mendiskusikan tentang realisasi pelaksanaan kegiatan meliputi survey awal untuk mengetahui tingkat pengetahuan mitra, kondisi lingkungan dan proses perijinan kepada pihak terkait, koordinasi dengan perangkat desa dan mitra untuk menentukan waktu, tempat pelaksanaan serta materi yang dibutuhkan mitra (4) FGD keempat mendiskusikan tentang evaluasi kegiatan.

\section{Kegiatan Penyuluhan}

Pada kegiatan penyuluhan (Gambar 2) ini disampaikan materi tentang pemanfaatan ot organic berbahan campuran jerami padi, daun bawang merah serta tanah liat (clay). Pengabdi memberikan beberapa contoh state of the art pembuatan pot organik yang telah dilakukan di beberapa daerah. Kegiatan yang telah dilaksanakan meliputi penyiapan peralatan dan perlengkapan pelatihan, penyusunan modul/materi pelatihan, dan penyuluhan tentang pemanfaatan pot organik.

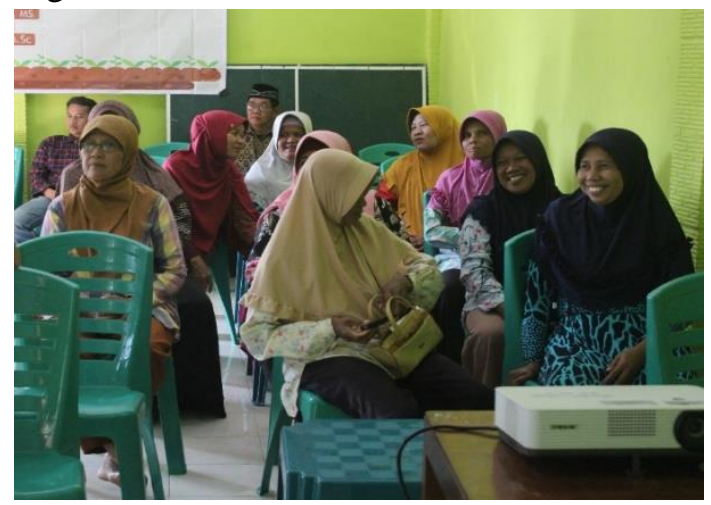

Gambar 3. Peserta kegiatan penyuluhan 


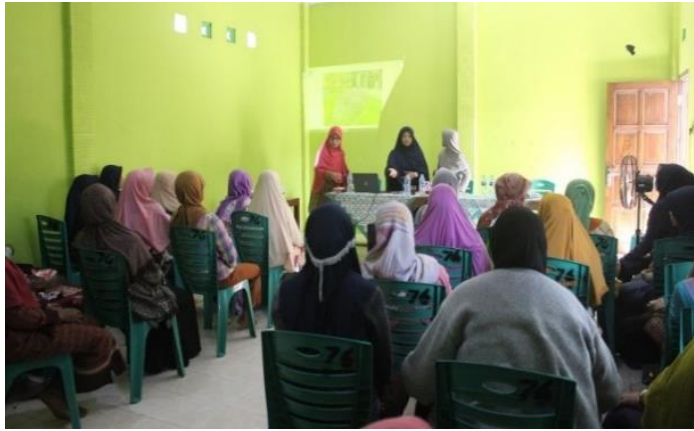

Gambar 3. Antusiasme peserta dalam mengikuti kegiatan penyuluhan pemanfaatan limbah jerami padi dan daun bawang merah

\section{Kegiatan Pembuatan Pot Organik}

Bahan-bahan yang digunakan sebagai bahan pembuatan pot organik berbahan campuran limbah jerami dan daun bawang merah adalah $1 \mathrm{~kg}$ jerami yang telah dipotong kecil-kecil, $1 \mathrm{~kg}$ daun bawang merah, dipotong kecil, $1 \mathrm{~kg}$ pupuk kendang, $0,5 \mathrm{~kg}$ tepung kanji, dan air secukupnya. Alat-alat yang digunakan meliputi ember, pisau, sarung tangan, pengaduk kayu, penumbuk.

Cara membuat pot organik

1. Jerami dan daun bawang merah dipotongpotong kecil.

2. Pupuk kandang dihaluskan, disaring dengan ayakan lalu campurkan dengan jerami dan daun bawang merah.

3. Masukkan tepung kanji lalu beri air secukupnya sampai dirasa cukup untuk dibentuk/cetak

4. Cetak/press menggunakan cetakan pot.

5. Lalu jemur sampai kering, setelah kering pot siap digunakan

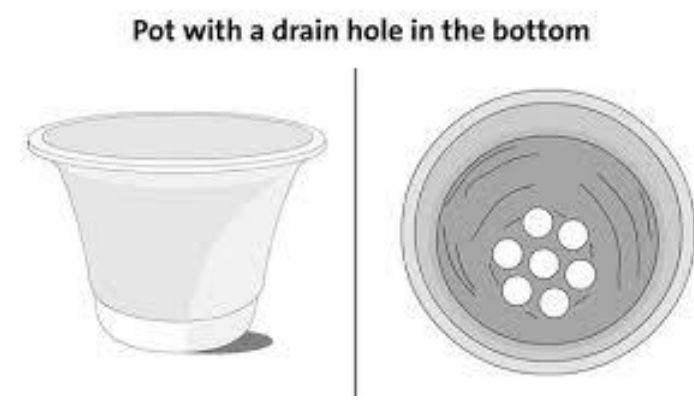

Gambar 4. Ilustrasi model pot organik berbahan jerami dan limbah daun bawang merah

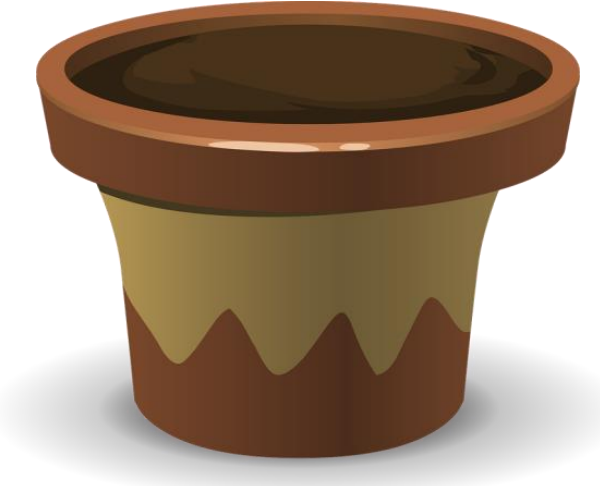

Gambar 5. Ilustrasi lain model pot organik berbahan jerami dan limbah daun bawang merah
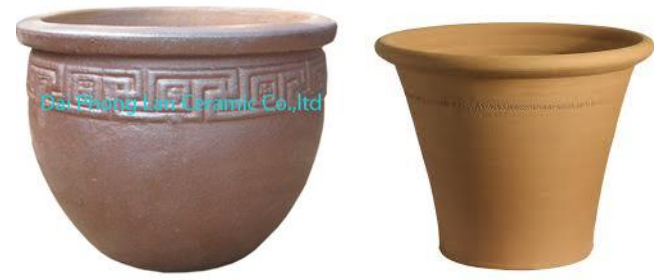

Gambar 6. Alternatif model lain pot organik berbahan jerami dan limbah daun bawang merah
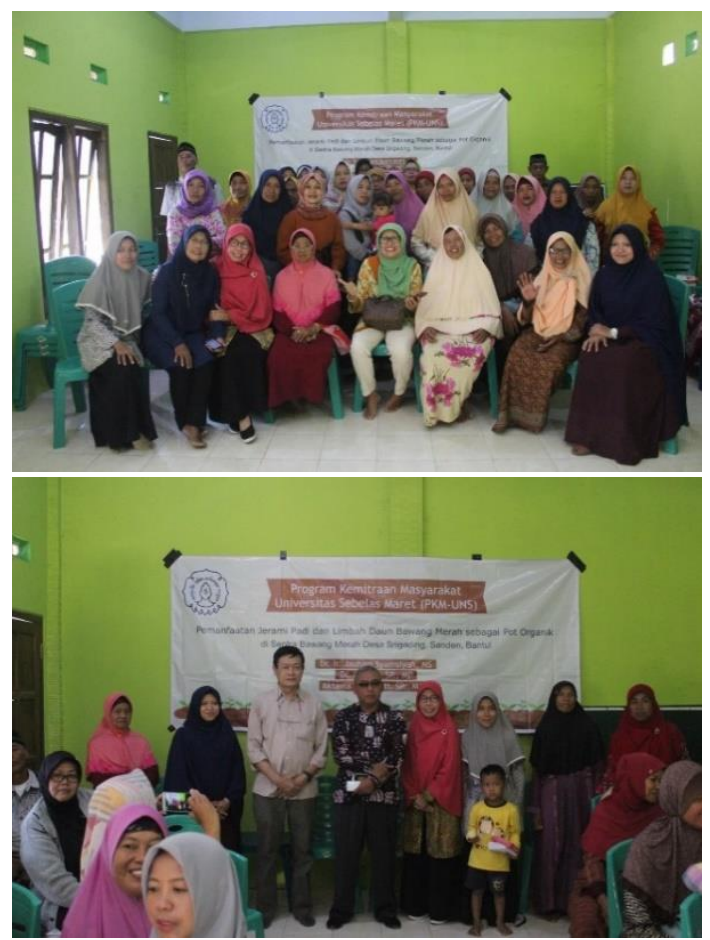

Gambar 5. Berfoto Bersama dengan perangkat desa dan peserta pelatihan pembuatan pot organik 


\section{KESIMPULAN DAN SARAN}

\section{Kesimpulan}

1. Respon masyarakat terhadap pemanfaatan jerami padi dan daun bawang merah sebagai bahan campuran pot organic sangat tinggi.

2. Pot organik bisa dikembangkan untuk mengurangi limbah dan meningkatkan nilai tambah barang

\section{Saran}

Perlu adanya penilaian kelayakan usaha dan pendampingan agar produk pot organic bisa dijual untuk umum.

\section{Ucapan Terima Kasih}

Tim Pengabdi menyampaikan ucapan terima kasih kepada Universitas Sebelas Maret yang telah mendanai program pengabdian ini melalui skim Program Kemitraan Masyarakat (PKM), Tahun Anggaran 2019.

\section{DAFTAR PUSTAKA}

Akhir, J., Allaily., D. Syamsuwida., S.W.R.Budi. 2018. Daya Serap Air dan Kualitas Wadah Semai Ramah Lingkungan Berbahan Limbah Kertas Koran dan Bahan Organik. Jurnal Rona Teknik Pertanian. Vol 11 No 1. p: 23-35

Badan Pusat Statistik. 2017. Kabupaten Bantul Dalam Angka. Badan Pusat Statistik Kabupaten Bantul.

Budi, W.S, Andi Sukendro, Lina Karlinasari. 2012. Penggunaan Pot Berbahan Dasar Organik untuk Pembibitan Gmelina arborea Roxb. di Persemaian. Jurnal Agronomi Indonesia 40 (3) : 239 - 245 (2012)

Isroi. 2013. Pemanfaatan Jerami Padi sebagai Pupuk Organik In Situ untuk Memenuhi Kebutuhan Pupuk Petani. www.ibriec.org Juli 2013: 1(1) 7-12. Diakses pada tanggal 25 Januari 2016.

Nursyamsi. 2015. Bipot Sebagai Media Semai Pengganti Polybag yang Ramah Lingkungan. Info Teknis EBONI Vol 12 No 2: 121-129

Suita, E., D.J. Sudrajat, R. Kurniaty. 2017. Pertumbuhan Bibit Kalindra pada Beberapa Komposisi Media Semai Cetak di Persemaian dan Lapangan. Jurnal Penelitian Hutan Tanaman. Vol 14 No 1. p.73-83 